\title{
Glacial varves at the distal slope of Pandivere-Neva ice-recessional formations in western Estonia
}

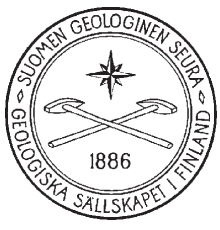

\author{
Peeter Talviste ${ }^{1)}$, Titt $\mathrm{Hang}^{2)}$ and Marko Kohv ${ }^{2)}$ \\ 1) IPT Projektijuhtimine OÜ, Kopli 96-1, 10416 Tallinn, Estonia \\ 2) Department of Geology, Institute of Ecology and Earth Sciences, \\ University of Tartu, Ravila 14a, 50411 Tartu, Estonia
}

\begin{abstract}
The distribution and varve thickness data of Late Weichselian varved clay were analyzed to describe the proglacial sedimentary environment, ice recession and water-level changes in the Baltic Ice Lake at the distal position of Pandivere-Neva (13.5-13.1 ka BP) ice- recessional formations in western Estonia. According to vertical changes in natural water content, fabric and varve thickness, four clay units were distinguished, reflecting a change in the sedimentary environment from ice-proximal to distal conditions. The varved clay complex is locally interrupted by a massive silty-clay unit, interpreted as an icedrift material during the stagnation of the glacier margin at the Pandivere-Neva line. Varve correlation gave a 294-year-long floating varve chronology. According to total varve thickness and the relation between thicknesses of seasonal layers, an about 130year period of ice-proximal conditions in the study area was followed by a rapid (within ca 20 years) change to more distal conditions. The presented varve chronology does not cover the entire period of proglacial conditions in the area, as all studied clay sections displayed an erosional discontinuity at the upper contact. In total, ca $4 \mathrm{~m}$ of selective post-sedimentary erosion of clay is attributed to wave erosion due to a water-level drop after the final drainage of the Baltic Ice Lake. It is concluded that the Yoldia Sea minimum level in the Pärnu area was 0 to $-2 \mathrm{~m}$ a.s.l.
\end{abstract}

Keywords (GeoRef Thesaurus, AGI): glaciolacustrine sedimentation, clay, varves, water content, chronology, deglaciation, Baltic Ice Lake, Weichselian, Pärnu, Estonia

Corresponding author email: peeter@geotehnika.ee 


\section{Introduction}

The decay of Late Weichselian Ice Sheet in the southeastern sector of the Scandinavian Glaciation produced huge volumes of meltwater and led to the formation of extensive proglacial bodies of water in front of the receding ice margin. During the earlier deglaciation stages roughly between 16.0 and 14.2 ka BP, the system of eastern proglacial lakes with Lake Privalday (Kvasov, 1979; Björck, 1995; Mangerud et al., 2004) and Glacial Lake Peipsi (Hang, 2001; Rosentau et al., 2009) drained westwards to the early Baltic Ice Lake (BIL) in the southern Baltic Sea depression. When the ice margin retreated from the Valdemarpils marginal line to the Pandivere-Neva line (Fig. 1, lines 6 and 7) between 14.0 and $13.3 \mathrm{ka}$ BP (Kalm, 2006; Kalm et al., 2011), the BIL waters reached the eastern coast of the Gulf of Riga and the southwestern coast of Estonia. In our study area in the surroundings of the town Pärnu at the northeastern coast of the Gulf of Riga, the water depth of the BIL at that time was more than $40 \mathrm{~m}$ (Rosentau et al., 2009). According to spatial distribution and bathymetry models of the BIL in the eastern Baltic (Rosentau et al., 2009; Vassiljev et al. 2011), relatively deep water (20-40 m) conditions remained in western Estonia at least until the ice margin stood at Salpausselkä I formations

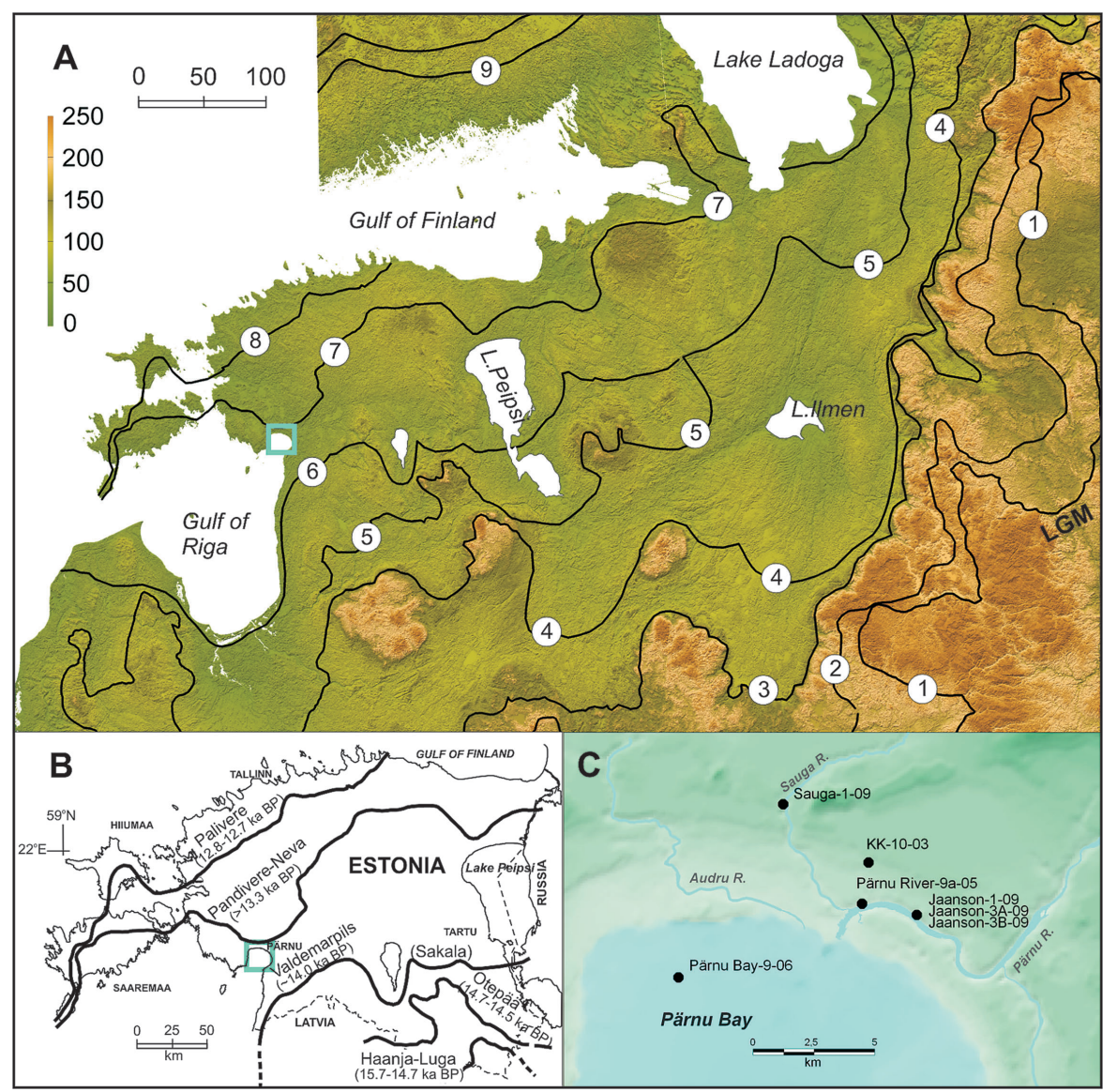

Fig. 1. Location of the study area in coastal Estonia, eastern Baltic, with Late Weichselian ice-marginal formations (Kalm, 2010) indicated (A), corresponding ages indicated according to Kalm (2006) (B), and the positions of the coring sites indicated (C). Ice-marginal zones: 1 = Last Glacial Maximum(LGM), 2 = Vepsian in Karelia and western Russia (Baltija, Pomeranian), 3 = Sebezha and Krestets in Russia and Karelia (South Lithuanian), 4 = Haanja-Luga in Russia and Estonia, Linkuva in Latvia (North Lithuanian), 5 = Otepää, 6 = Valdemarpils and Sakala in Latvia and Estonia, $7=$ Pandivere-Neva in Estonia, Russia and Karelia, 8 = Palivere, 9 = Salpausselkä I (Rugozero in Karelia). 
(12.3-12.1 ka BP) in southern Finland. The longlasting (>1000 yrs) deep-water BIL stage in western Estonia left behind widely distributed fine-grained glaciolacustrine sediments, including rhythmically deposited clays. Glacial varved clays with their characteristic summer (silty) and winter (clayey) laminas are suggested to reflect seasonal variations in sediment deposition in the proglacial lake (De Geer, $1884,1940)$. The thickness changes, inside structure and fabric of the varves can produce more details about the proglacial environment, water depth and deglaciation. In this paper, we analyse the distribution of varved clay and varve thickness changes, in order to describe the proglacial sedimentary environment, to characterize the ice recession prior to and/or during the formation of Pandivere-Neva icemarginal features and to detect possible signs of water-level changes of the BIL in the Pärnu area.

\section{Geological setting}

The study area (Fig. 1) embraces the coastal lowland of Estonia south of the Pandivere-Neva belt of ice-marginal formations at the back of Pärnu Bay. The surface of Devonian sandstones is at an altitude of -10 to $-15 \mathrm{~m}$ (Tavast \& Raukas, 1982). The entire area is covered by grey loamy till of Late Weichselian age followed by glaciolacustrine varved clay or silt with average thickness of ca $10 \mathrm{~m}$. The upper surface of clay dips towards the south. The Holocene marine sand covering the glaciolacustrine deposits is normally $2-3 \mathrm{~m}$ thick $(10 \mathrm{~m}$ as a maximum) but it can be absent locally.

The clays in the study area are characterized by distinct lamination and easily distinguishable seasonal layers. Varves are usually thick and clayey with silty microlayers in some intervals (Pirrus, 1968; Hang et al., 2007). Ripple marks, erosional features and synsedimentary disturbances are rare (Pirrus, 1968; Saarse \& Pirrus, 1988; Saarse, 1992). A massive silty-clay unit (0.40-8 $\mathrm{m}$ in thickness) with dispersed sand grains has been described within the varved clay complex in the northwestern part of Pärnu Bay and in the town of Pärnu (Hang et al., 2007). Its composition corresponds to clayey waterline glacial diamicton, earlier described from western Estonia (Kadastik \& Kalm, 1998).

The Pandivere-Neva ice-marginal zone in Estonia, which starts from the West Estonian Archipelago and continues on the mainland towards the northeast (Fig. 1), was formed 13.5-13.3 ka BP (Hang, 2001; Saarnisto \& Saarinen, 2001; Kalm, 2006; Kalm et al., 2011). Most often this zone is correlated with the Neva zone in northwestern Russia (Raukas et al., 1971; Lundqvist \& Saarnisto, 1995; Raukas et al., 2004; Kalm, 2010). The Pandivere-Neva zone forms a curved and interrupted belt of push end-moraines, glaciofluvial deltas and eskers (Karukäpp \& Raukas, 1997). Due to Holocene wave erosion these forms have been levelled and the height of these features range only from a few metres up to $20 \mathrm{~m}$. North to northwest of Pär$\mathrm{nu}$, the Pandivere-Neva formations are buried under younger marine sediments. The study area is located at the distal slope of the Pandivere-Neva formations.

\section{Material and methods}

Seven undisturbed sequences of varved clay were extracted with a Russian-type peat corer within the town of Pärnu and from the bottom of Pärnu Bay (Fig. 1). One metre long sections of the sediment core were wrapped in plastic film and placed in half PVC tubes for transport. In the laboratory, the core surface was cleaned, sediments were described and the thickness of each seasonal layer was measured. Construction of varve graphs followed the traditional method introduced by De Geer (1940). The cores were placed side-by-side and the correlation among seven cores was made directly on the sediments, considering not only layer thickness, which can vary in different sequences, but also other parameters, such as bedding characteristics, colour and interseasonal layers. The total mean varve thickness curve is based on all correlated varve diagrams.

Logs from 848 geotechnical cores from the database of the company IPT Projektijuhtimine OÜ were used to compile the distribution map of varved clay in the town of Pärnu. The surfaces of till (encountered in 310 corings), glaciofluvial deposits (encountered in 171 corings) and proglacial clay 
were interpolated with exact linear kriging interpolator and smoothed with a Gaussian low-pass filter within the software package Surfer 9.0 (Golden Software Inc.).

Different clay facies were identified on the basis of vertical differences in natural water content and changes in varve character as discussed in the text. Earlier results of grain-size analysis of 105 samples, taken across a number of seasonal layers from 11 geotechnical cores, were used to describe the mean grain-size distribution of glacial varved clay in Pärnu (Hang et al., 2007). The natural water content of 112 multi-annual and 52 seasonal layer samples from the Jaanson-1-09 sequence was estimated as the difference between wet sample weight and sample weight after drying at $105^{\circ} \mathrm{C}$ for $24 \mathrm{~h}$. The colour of sediments was indexed according to the Munsell Colour Chart (1998).

\section{Results}

\subsection{Distribution of varved clays in the Pärnu area}

According to 151 irregularly located corings, the clay thickness in Pärnu decreases from a maximum of $23 \mathrm{~m}$ in the northwestern to $2-6 \mathrm{~m}$ in the southeastern part of the town (Fig. 2A). The average thickness of clay exceeds $11 \mathrm{~m}$ (Fig. 2B) whereas clay is missing only in a few localities. Locally rapid changes in clay thickness are due to underlying topography (Fig. 3). The upper surface of Late Weichselian till, described by 310 geotechnical corings in the town and adjoining areas, displays southwardly opened depression from -20 to 5-10 m above present sea level (a.s.l.). The slopes of the depression are gentle, with the $0 \mathrm{~m}$ a.s.l. isoline following rough-

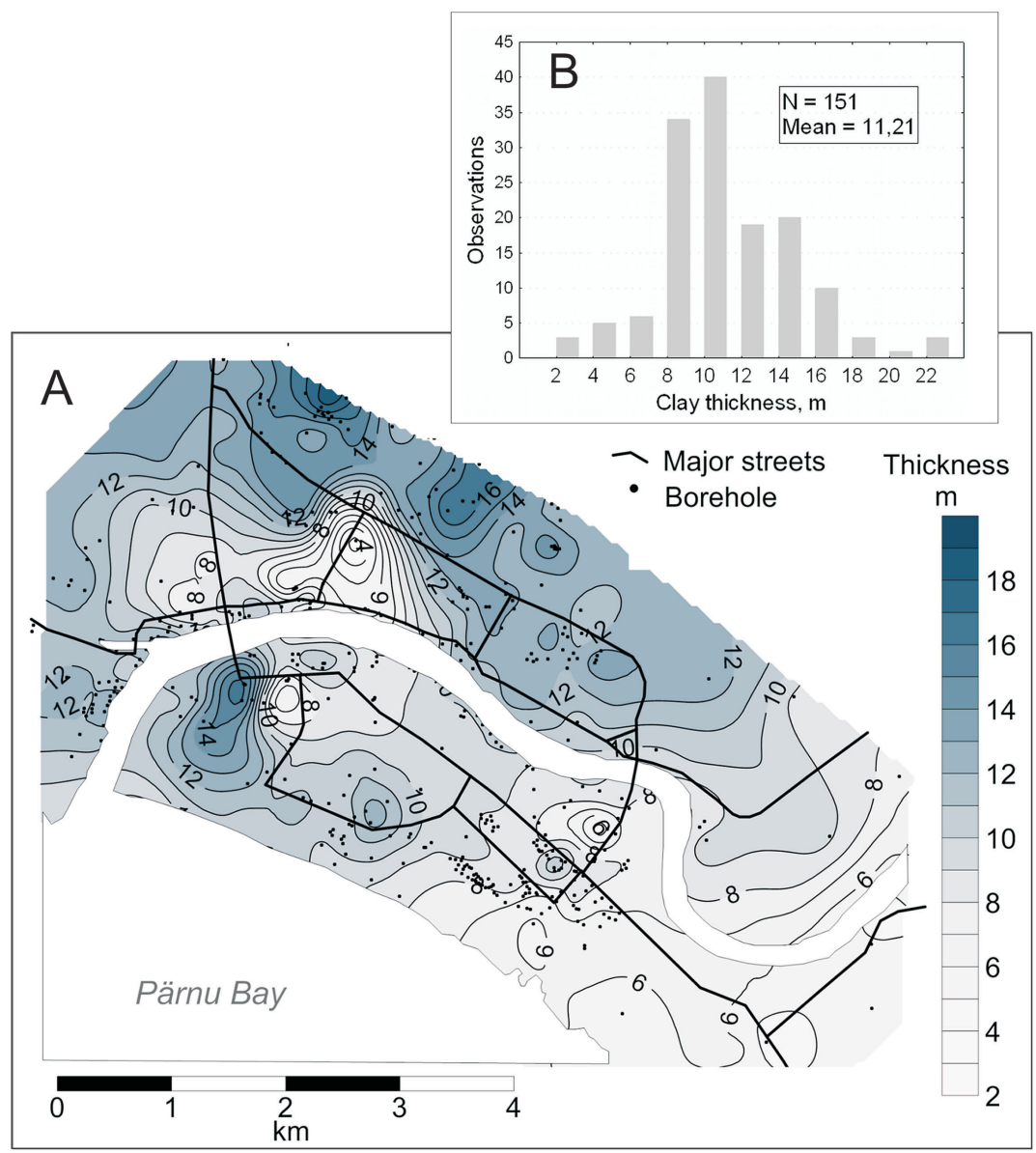

Fig. 2. Thickness distribution (A) and thickness change $(B)$ of the varved clay complex in the town of Pärnu based on logs of 151 geotechnical cores from the database of IPT Projektijuhtimine OÜ. 


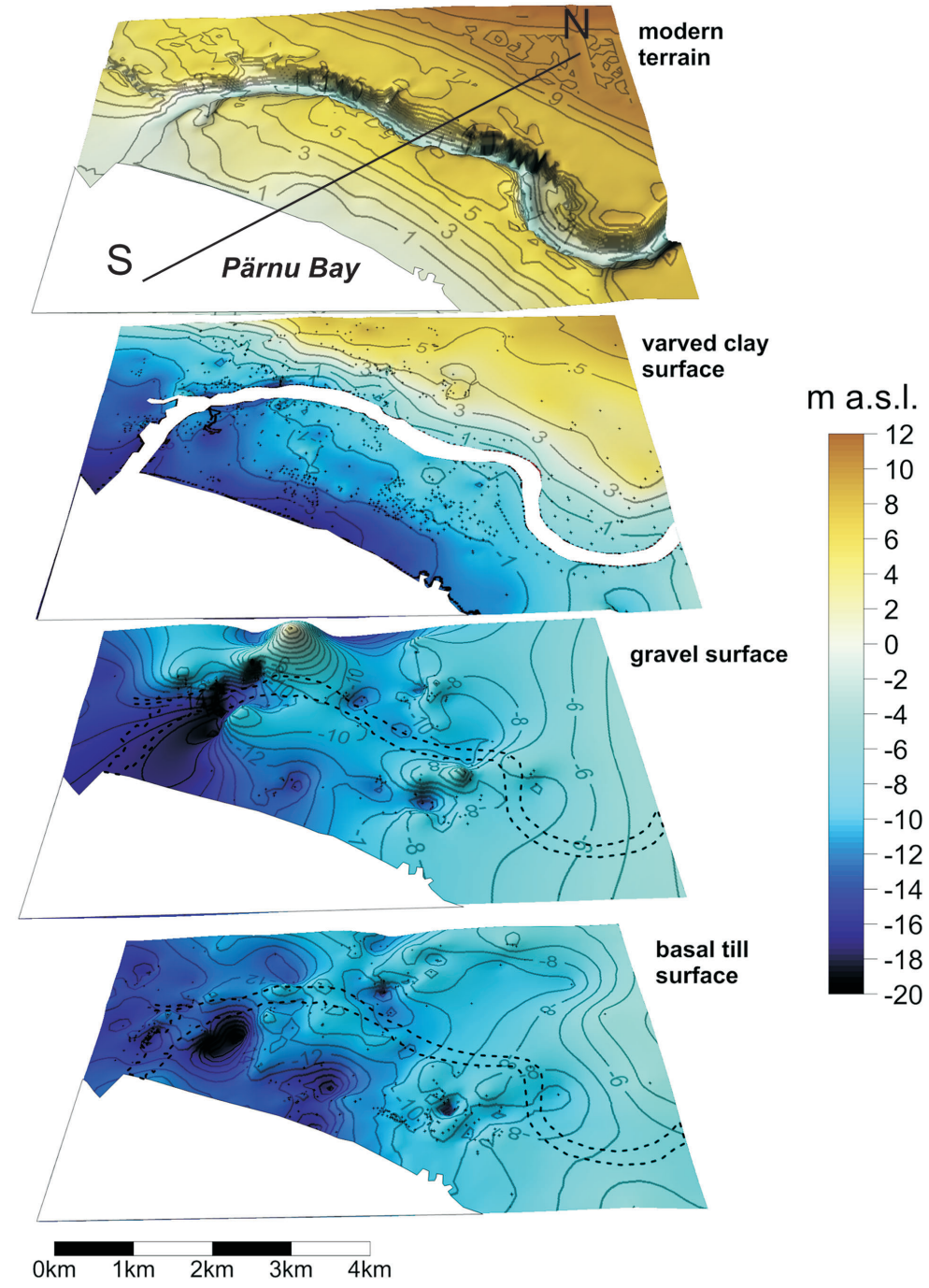

Fig. 3. Surface topography of the varved clay in Pärnu against the background of the underlying till topography and modern terrain. Maps compiled according to logs of 848 geotechnical corings (black dots) from the database of IPT Projektijuhtimine OÜ. The solid line indicates the location of the generalized geological cross section presented in Fig. 7 . ly the configuration of the present-day coastline of the Pärnu Bay at a distance of about 3-5 km onshore. The bottom of the depression is jointed by 2-10 m deep kettles with a diameter less than 200 m (Fig. 3). Glaciofluvial sand and gravel are locally present at the till surface, enhancing the irregular topography underlying glacial clay (Fig. 3).

Glaciolacustrine clay and silt cover the glacial till and/or glaciofluvial deposits. The rather flat upper surface of clay is gently sloping towards the south, being at an altitude of $-8 \mathrm{~m}$ ca $5 \mathrm{~km}$ offshore and $-2.5 /-3 \mathrm{~m}$ at the current coastline of Pärnu Bay. At a distance of ca $3 \mathrm{~km}$ north of the present coastline, the altitude of the clay surface rises rapidly from zero to $4 \mathrm{~m}$ (Fig. 3). Further to the north, the altitude of the clay surface rises gently up to 9$10 \mathrm{~m}$. The Holocene marine and aeolian fine sands and silts covering the clay are mostly $2-3 \mathrm{~m}$ thick and are absent only locally. Although in the study area the Pärnu River valley cuts the whole sand and clay complex, no outcrops are available for the clay studies and all descriptions presented below are based on coring data.

\subsection{Natural water content of clay}

The textural and structural properties of varved clay in the Pärnu area have been found to be highly correlative with the natural water content (Vilo, 1986; Hang et al., 2007; Kohv et al., 2009; 2010). Thus 
the regular vertical changes in water content have served as a basis for distinction of five different lithological units (A-E) in the clay complex (Talviste, 1988; Hang et al., 2007). In order to summarize the vertical changes in water content and to justify these changes to the varve and/or seasonal layer thickness changes, the clay sequence of Jaanson-1-
09 was studied in detail (Fig. 4). According to changes in the natural water content, four clay units were distinguished. The water content gradually decreases downwards from $80 \%$ in unit B to $30-60 \%$ in the lowermost portion of unit E (Fig. 4). Clay unit $\mathrm{B}$ comprises the uppermost $2 \mathrm{~m}$ with a series of winter layer dominated clayey distal varves having

\section{A Test site Jaanson-1-09}

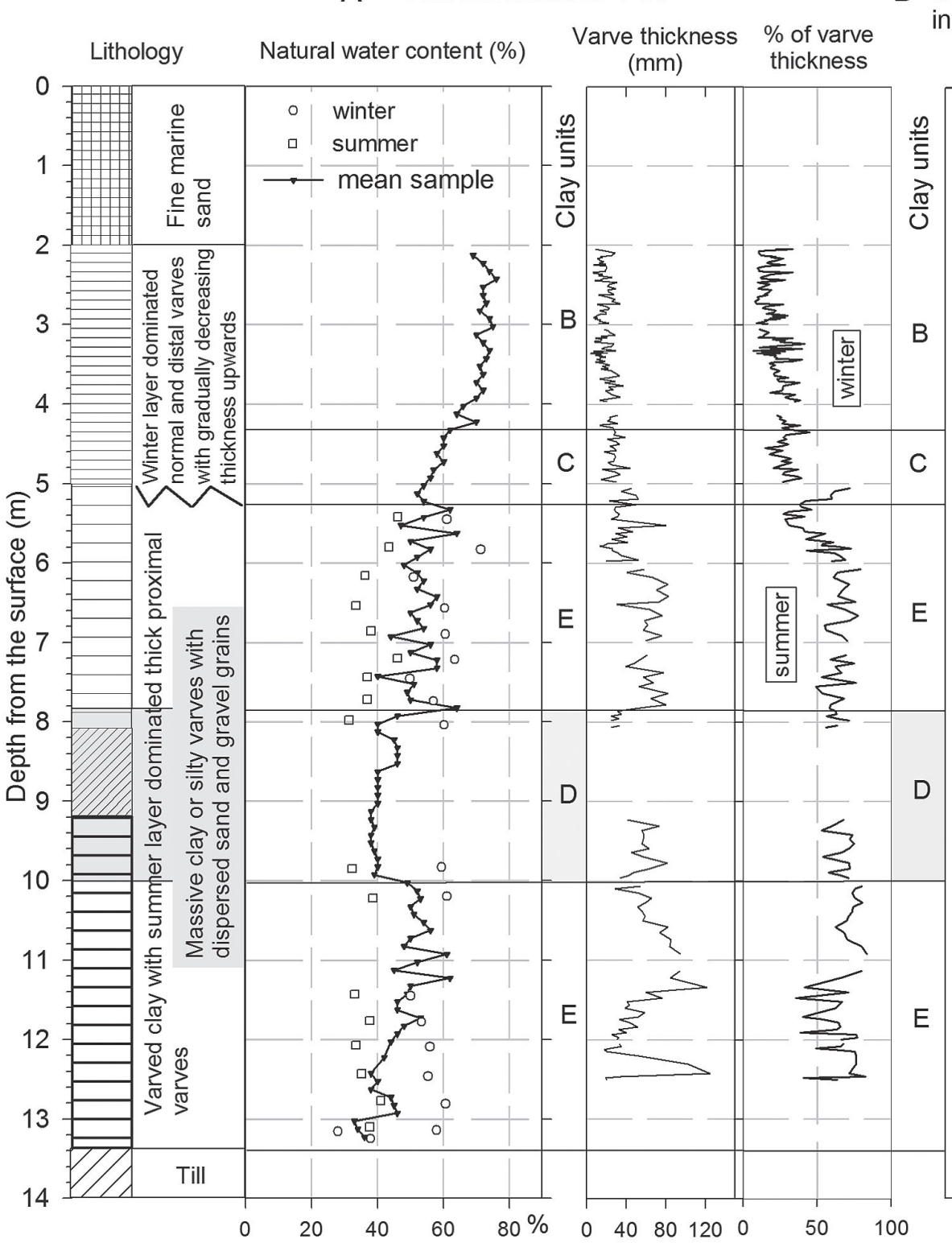

B Grain-size distribution (\%) in different clay units

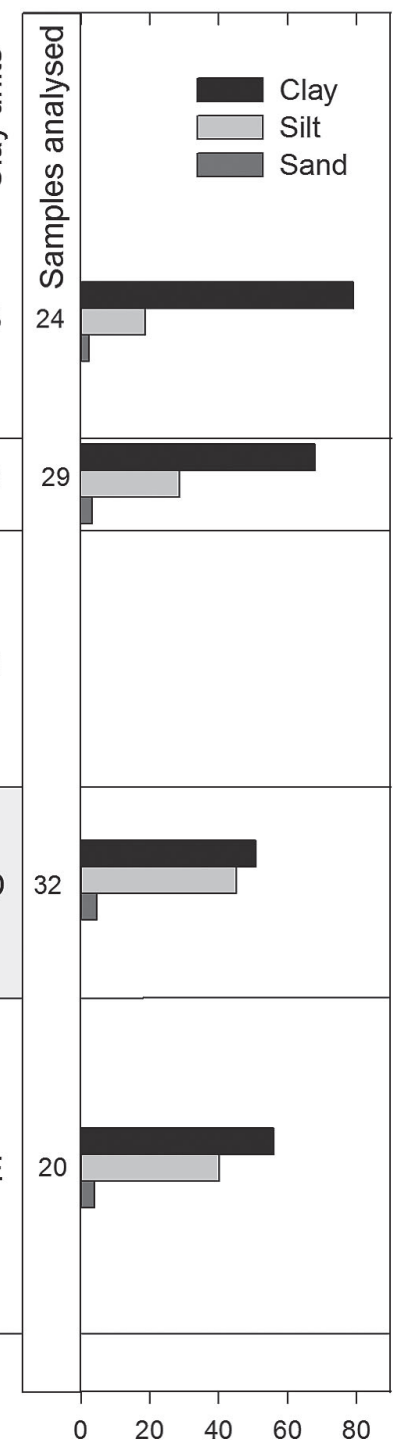

Fig. 4. Lithology and different clay units distinguished according to vertical changes in the natural water content, varve thickness and the ratio of seasonal layer thickness within a varve at the Jaanson-1-09 test site (A), and generalized grainsize composition of clay units (B) based on analyses of 105 multi-annual samples. Grain-size data from the archive of IPT Projektijuhtimine 0Ü. For location of the Jaanson-1-09 test site see Fig. 1. 
rather stable water content between $70 \%$ and 80 $\%$ (Fig. 4). Due to very thin lamination, the water content of seasonal layers in unit B was not analysed. According to geotechnical corings, this unit may be up to $6 \mathrm{~m}$ thick in Pärnu and is absent locally. In clay unit C (Fig. 4), the water content decreases continuously downwards from $70 \%$ to $50 \%$. Where present, this unit is always recognized on top of clay unit $\mathrm{E}$ and is represented by varved clay with varve thickness increasing downwards (Fig. 4). Unit $\mathrm{C}$ is interpreted as a transitional interval from thin winter layer dominated distal varves to thick summer layer dominated proximal series of varves. The water content of clay in unit E varies distinctly between $60 \%$ and $30 \%$. This unit consists of thick summer layer dominated proximal varves. Clay unit $\mathrm{E}$ is interrupted by unit $\mathrm{D}$, composed of non-laminated silty clay with a constant water content around $40 \%$ (Fig. 4). The water content of silty summer layers and clayey winter layers within an individual varve is different, ranging from $15-25 \%$ in units $B$ and $\mathrm{C}$ to as much as $60 \%$ in unit $\mathrm{E}$. The boundaries between the units of clay are transitional rather than fixed.

Unit A, missing from figure 4, has earlier been described as desiccated clay with the water content of 20-60\% (Kohv et al., 2010). It has been recognized only locally in clay sequences at an altitude of more than $5 \mathrm{~m}$ and is not present in the currently studied sequences.

\subsection{Varve thickness changes and local varve chronology}

In order to describe the sedimentary environment across the study area, varve thickness changes were analysed and the correlation of seven sediment cores from irregularly spaced coring sites, located at a maximum distance of $9 \mathrm{~km}$ from each other, was provided (Fig. 1). A local varve chronology comprising 294 consecutive varve years was constructed (Fig. 5). Clear varve-to-varve correlation is possible in the older part of the chronology up to the local year 150 (Fig. 5). Correlation from this level onwards is more complicated because of large variations in the thickness of individual varves and inc- reasing dominance of clayey winter layers lacking specific textural or structural characteristics useful for varve correlation between sequences. The length of the chronology (294 years) certainly underestimates the duration of proglacial conditions as all varve series have erosional discontinuity at the upper contact with the overlying sands, pointing to post-sedimentary erosion at all locations.

Five out of seven varved sections discussed are interrupted by an interval of massive clay with dispersed sand and gravel grains and few dropstones. The thickness of this massive clay unit varies from $0.40 \mathrm{~m}$ (Pärnu Bay-9-06 core) to $8 \mathrm{~m}$ (KK-10-03 core). The unit is missing in the Pärnu River-9A05 section (Fig. 5). According to varve correlation (Fig. 5), the massive clay unit appears in different cores at the same stratigraphical level between the varves 70 and 90 in local chronology. An interval of 20 silty varves with dispersed sand and gravel grains in both seasonal layers within a single varve corresponding to this unit is reported from the Pärnu River-9A-05 core. Total varve thickness in this series of 20 varves is smaller compared to the neighbouring varves (Fig. 6). All investigated clay sequences display a rapid colour change from greyishbrown (10YR 4/2) to reddish-brown (10YR 5/3). The colour change appears on top of the interval of silty varves in the Pärnu River-9A-05 core and in other cases above the massive clay unit. As seen from the varve correlation, the colour change is synchronous across the studied sequences (Fig. 5).

The main trends in the thicknesses of Pärnu varves can be readily followed from the mean varve thickness graph (Fig. 6). Two main series of varves with gradual transition in between could be distinguished. Summer layers dominate (52-90\% of individual varve thickness) within thick (18-155 mm) varves in the lower portion of clay up to the year 130 in local chronology (Fig. 6). This series of varves is represented by a greenish-grey silty summer layers with alternating silt and sandy silt laminas or in places ripple bedding. Winter layers consist of reddish-brown massive clay. Seasonal layers are easy to distinguish.

The upper series of varves from the year 150 onwards in local chronology is characterized by a 


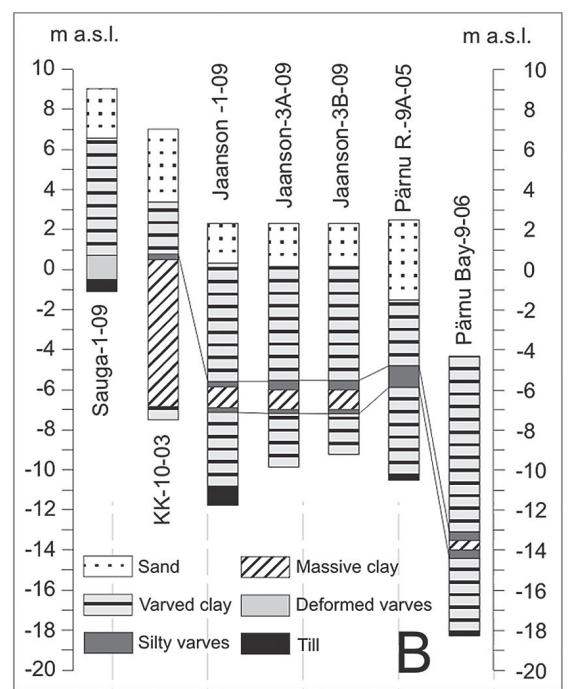

Fig. 5. Correlation of varve graphs from the investigated sites (A). The open square indicates that the bottom varve has been reached; the arrow shows that more varves are present in the basal part of the sequence; $D$ indicates the stratigraphical position of the massive clay unit of variable thickness; the solid line marks the colour change and the light grey colour indicates the interval of 20 silty varves with dispersed sand and gravel grains. (B) Lithology with the indication of clear correlation levels. For location of the sites see Fig. 1.
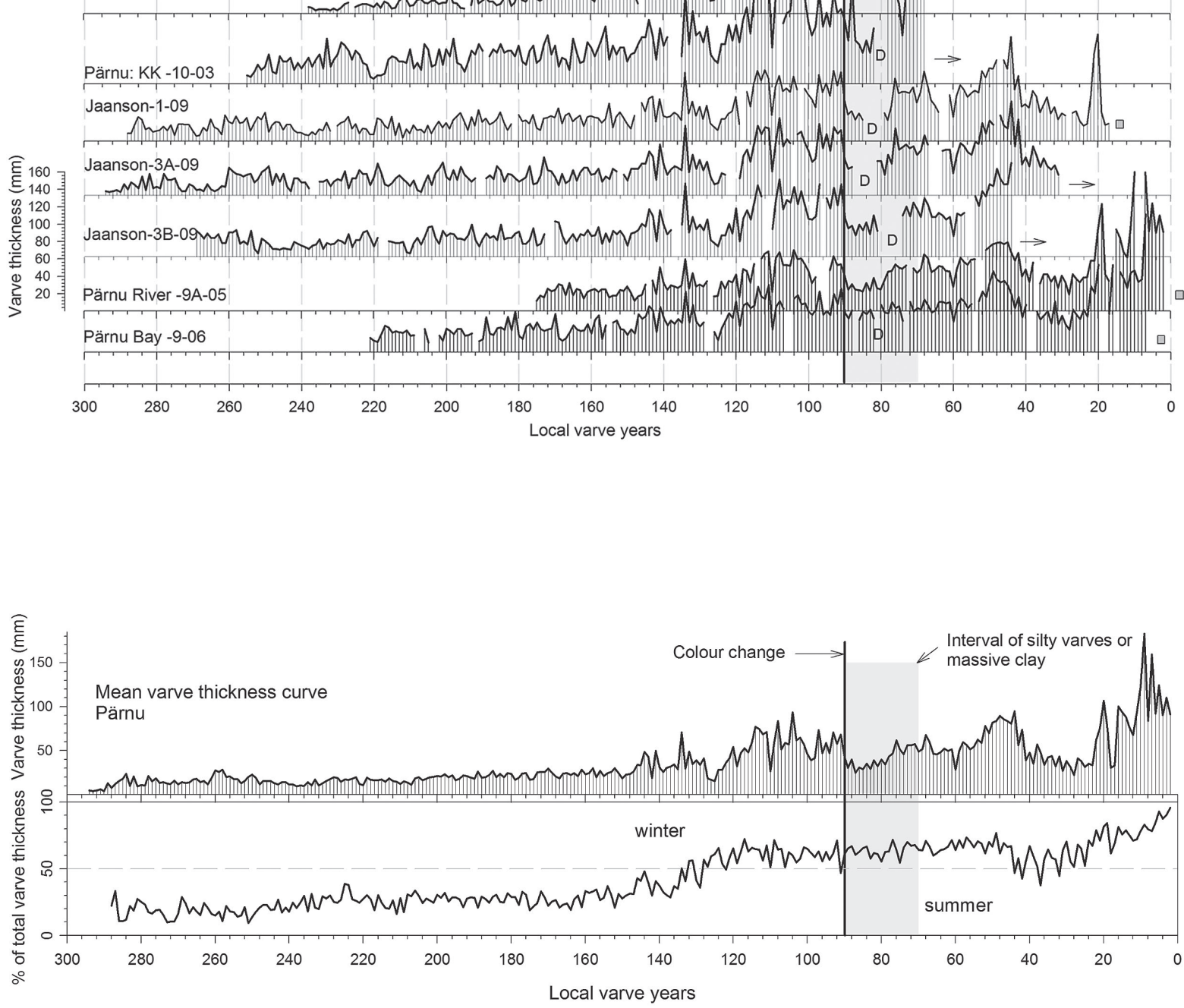

Fig. 6. Mean varve thickness curve for the Pärnu local varve chronology based on the varve thickness measurements displayed in Fig. 5. The lower diagram summarizes the relation between winter and summer layer within each varve. The solid line marks the colour change, and the light grey colour indicates the interval of 20 silty varves or massive clay. 
decreased total varve thickness $(10-40 \mathrm{~mm})$ compared to the underlying varves and the dominance of the winter layer (60-90\%) within a couplet (Fig. $6)$. In the upper portion of this group, visual distinction between the varves and seasonal layers is problematic. This is why the true number of varves in this group is usually greater than shown in any of the varve graphs. The upper contact of the varve series is erosional.

The transition between the two series consists of ca 20 varves between the years 130 to 150 in local chronology (Fig. 6). This group of varves consists of greenish-grey massive silt in the summer layers and dark brown massive clay in the winter layers. The most characteristic feature of this group of varves is rapid decrease in total varve thickness with the corresponding change in relation to seasonal layer thickness within a varve.

\section{Discussion}

Earlier investigations (Talviste, 1988; Hang et al., 2007; Kohv et al., 2010) have zoned the varved clay complex in Pärnu on the basis of vertical changes in various geotechnical parameters. Up to five clay facies have been distinguished. In the current study, the thickness, inside structure and natural water content of varves were used to determine vertical changes and adjust these to the earlier zonation with the aim of reconstructing the sedimentary environment. According to changes in the natural water content, four clay units (B-E) were distinguished (Fig. 4). The decrease in water content downwards from $80 \%$ in unit B to $30-60 \%$ in the lower portion of unit $\mathrm{E}$ is correlative with the changes in grainsize composition (Fig. 4). Although seasonal layers distinctly differ in their common texture (Stevens, 1987; Hang et al., 2007), analysis of multi-annual samples supports the above zonation of the clay complex as the content of clay fraction is decreasing and the silt fraction is increasing towards the depth (Fig. 4). The non-laminated clay unit D with the lowest water content has the coarsest texture.

Varve thickness changes also demonstrate a rather good correlation with the natural water content of the sediment as a series of summer-layer-domi- nated thick varves has lower water content than the upper series of winter-layer-dominated thin varves (Fig. 4). The boundary between the above two varve series is transitional, including ca 20 varves with rapidly increasing relative thickness of clayey winter layers within a varve, accompanied by a rather rapid but gradual upward increase in water content. The lower series of summer layer dominated proximal varves has been formed in varying sedimentary conditions close to the ice margin. This is also reflected in the texture of summer layers which in the proximal series of varves contain alternating silt or sandy silt laminas demonstrating varying pulsating influx, while summer layers in distal varves constitute of massive clayey silt. The incomplete series of the uppermost thin, winter layer dominated varves from the year 150 onwards in local chronology is interpreted as having formed in the distal part of the proglacial lake. The varve series $\mathrm{C}$ (local years 130-150) could be interpreted as a rapid proximity change in the sedimentary environment due to accelerated ice recession.

The most intriguing clay unit is unit $\mathrm{D}$, characterized by the lowest but very stable water content (Fig. 4). This massive silty clay with dispersed grains of sand and gravel and few dropstones is of scattered distribution, having maximum thicknesses in the northwestern Pärnu area but missing in the nearshore area of Pärnu Bay (Hang et al., 2008). According to varve correlation, presented in this paper (Fig. 5), unit D stratigraphically corresponds to the interval of 20 silty varves (local years 70-90) reported in the Pärnu River-9A-05 sequence. Formation of synchronous intervals of 20 silty varves and massive clay with the varying thickness is interpreted as ice-drift sedimentation during the stagnation of ice terminus at the Pandivere-Neva line. The amount of ice-drift material decreased in the distal direction and in most of the proglacial basin, the sedimentary environment still remained suitable for the accumulation of silty varves. The possible stagnation in ice recession at the Pandivere-Neva line was accompanied by decreased melting, reflected in the reduced total varve thickness during the above interval of 20 varves (local years 70-90). Rapid increase in varve thickness (from the year 90 on- 
wards) following this interval can reflect the accelerating melting and ice recession from the Pandivere-Neva line with corresponding increase in sediment inflow. For further conclusions additional lithostratigraphical and sedimentological studies, as well as varve correlation are needed across the Pandivere-Neva formations.

In this study, a good correlation was established between the natural water content, total varve thickness and the ratio of seasonal layer thickness within a single varve, which justifies the use of the water content analysis as a basis for distinguishing and interpreting different units in the clay complex without time-consuming sedimentological and/or varve studies. These units have transitional boundaries reflecting gradual changes in the sedimentary environment. Desiccated clay of unit A has been locally recorded (Hang et al., 2007; Kohv et al., 2010) at a higher (more than $5 \mathrm{~m}$ ) altitude in the surroundings of Pärnu. The possible formation of this unit will be discussed below.

The erosional discontinuity at the upper contact of clay with the overlying marine sand points to post-sedimentary erosion in all localities discussed in this paper. Modelling results (Rosentau et al., 2009; Andrén et al., 2011; Vassiljev et al., 2011) do not reveal any low water-level episodes in the development of the BIL in the eastern Baltic before the final drainage event at 11650 yrs BP (Andrén et al., 2002). Unfortunately, clear geological evidence for determining the lowest water-level after the Billingen event are missing in western Estonia. The reason is high water stand episodes in the Holocene development of the Baltic Sea when the post-Billingen event shore marks and corresponding deposits were eroded. Although proglacial varved clays leave little space for the arguments about the water depth and water-level changes, some speculations can be derived from the altitude of the varved clay surface which, according to our results, is locally eroded. The varved clay surface displays a gentle scarp at a distance of ca $3 \mathrm{~km}$ onshore from the current shoreline, where the altitude of the clay surface increases from 0 to $4 \mathrm{~m}$ (Figs 3, 7). According to geotechnical studies (Kohv et al., 2010) supported by varve investigations in a few sections (Hang et al., 2007; 2008; 2010), the clay layer above this scarp exhibits a full series of clay units (A-E) distinguished in the proglacial clay of the Pärnu area (Fig. 7). Below the scarp, in the areas adjacent to

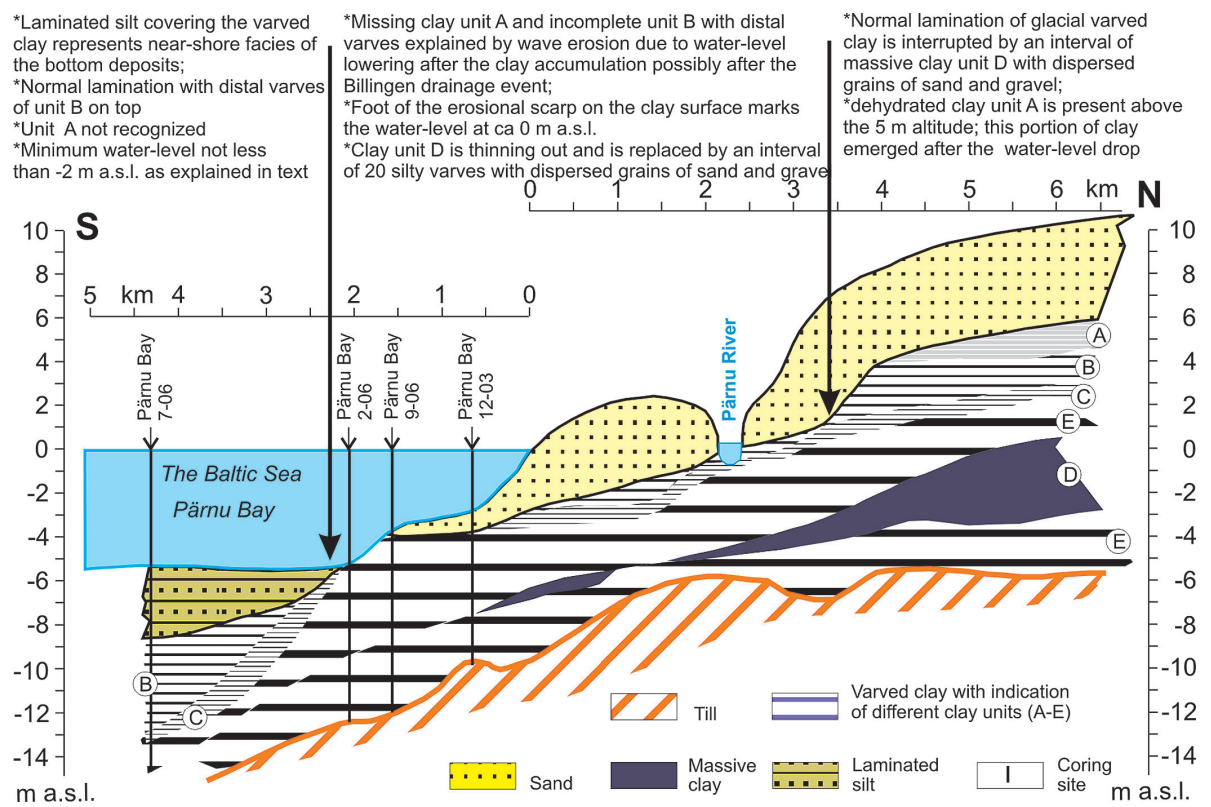

Fig. 7. Principle cross section through the town of Pärnu to Pärnu Bay (location indicated in Fig. 3) based on the logs of geotechnical cores (database of IPT Projektijuhtimine OÜ) in the town and logs of cores in Pärnu Bay (Hang et al. 2007, 2008). 
the current coastline, unit $\mathrm{A}$ is missing in the clay sections and unit $B$ is rather unstable in thickness and probably incomplete. Further offshore to Pärnu Bay, unit $\mathrm{B}$ is more completely represented and unit A is missing (Hang et al., 2008; 2010). Such a succession in clay facies together with the erosional discontinuity in the upper contact of clay sequences discussed in this paper point to the possible erosional origin of the scarp in the clay surface (Figs 3,7 ) and the location of the corresponding palaeo-shoreline at ca $0 \mathrm{~m}$ a.s.l.

The hypothesis of selective erosion of the clay surface in the study area is also supported by a good correlation between the thickness of the clay complex and the altitude of the clay surface (Fig. 8). Namely, the analysis of the relation between

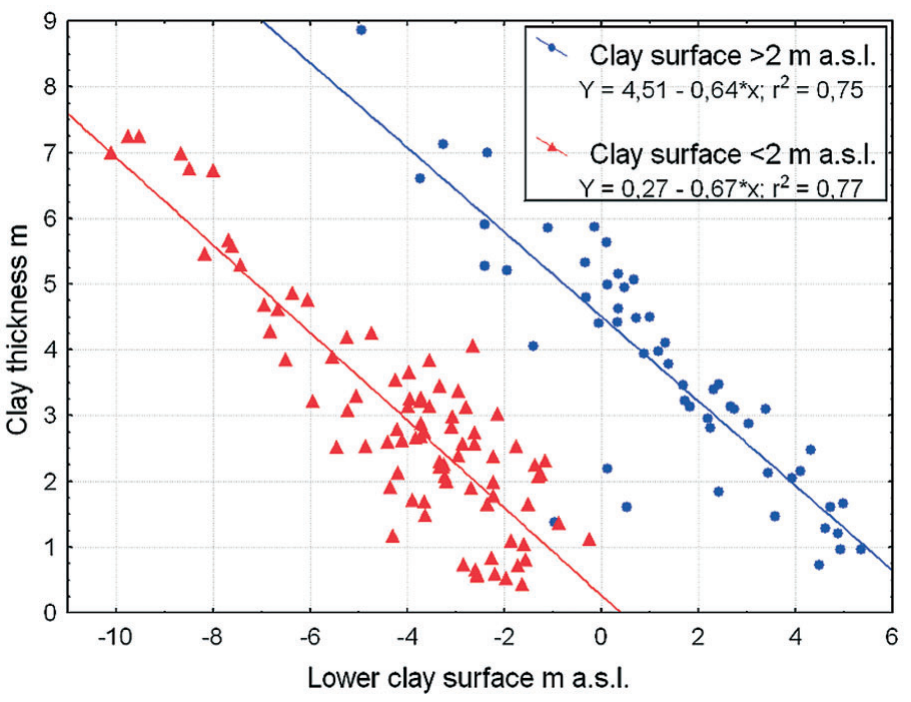

Fig. 8. The relationship between the altitude of the lower clay boundary and the thickness of the clay complex in 151 geotechnical cores in the town of Pärnu. Data from the database of IPT Projektijuhtimine OÜ. the altitude of the lower clay surface and the thickness of clay displays two groups of data sets, both reflecting an increase in sediment thickness with decreasing altitude (Fig. 8). Linear trend lines for both groups of data show high $\mathrm{r}^{2}$ values (0.8266 and 0.769) and a rather similar slope component (Fig. 8). We found that the best characteristic for differentiating between the two groups is the altitude of the upper clay surface at $2 \mathrm{~m}$ a.s.l. Thus, at the sites with the clay surface above an altitude of $2 \mathrm{~m}$, the clay portion is regularly thicker than in the areas with the corresponding surface at a lower altitude. Nearly parallel trend lines reveal a difference in clay thickness of about $4 \mathrm{~m}$ between the two statistically defined groups. In our opinion, the clay sections with the lower boundary at a lower altitude have suffered from post-sedimentary erosion of about $4 \mathrm{~m}$. Four metres is also the height of the erosional slope in the clay surface (Fig. 3) above which the clay bed is thicker than in the nearshore area and also clay unit A appears (Fig. 7). We suppose that during the drop of the water-level and the following lowstand, wave erosion reached the lake bottom and the upper portion of glaciolacustrine clay was eroded in the area adjacent to the current coastline and the erosional scarp was formed on the clay surface (Fig. 7). The clay surface above the scarp emerged and due to periodic freezing-melting cycles and accompanying chemical and soil forming processes, the ca $2 \mathrm{~m}$ thick upper clay interval lost its varve structure and is recognized as desiccated clay of unit A.

The gradual upper contact of clay unit B with the Holocene bottom deposits of the Baltic Sea in the deeper $(>7 \mathrm{~m}$ ) part of Pärnu Bay indicates that the unit $\mathrm{B}$ is fully present there and that wave erosion during the lowest water-level after clay accumulation did not reach an altitude of ca -7 to -8 $\mathrm{m}$. As calculated from the wave length data (Kask \& Kask, 2004), and derived from the distribution of Holocene bottom deposits (Lutt, 1987; Hang et al., 2008), $5 \mathrm{~m}$ of the water column is critical for the wave-induced sediment transport/erosion in Pärnu Bay. For this to be true, the water-level in the bay could not have dropped below $-2 \mathrm{~m}$ with the corresponding wave erosion down to $-7 \mathrm{~m}$ a.s.l. Argued in this way, the lowest water-level in the study area after the Billingen drainage event is currently placed to an altitude of 0 to $-2 \mathrm{~m}$, which is rather similar to the earlier proposed Yoldia Sea minimum level in the Pärnu area between 3 and 0 $\mathrm{m}$ a.s.l. (Veski et al., 2005; Rosentau et al., 2009; 2011). 


\section{Conclusions}

1. A floating 294-year-long varve chronology has been established from the town of Pärnu, western Estonia. Varve comparison made directly on sediment sequences in the laboratory gave a convincing correlation.

2. The length of the presented chronology was determined by the longest varved section but because of post-sedimentary erosion, it underestimates the duration of the proglacial conditions in the area.

3. Selective post-sedimentary erosion of the clay surface of ca $4 \mathrm{~m}$ took place.

4. Vertical changes in the natural water content are correlative with changes in total varve thickness and with changes in the ratio of seasonal layer thickness within a single varve.

5. According to varve analysis, the sedimentary environment changed rapidly, within 15-20 years, to more distal after ca 130 years of iceproximal conditions in the study area.

6. According to varve correlation, a $0.4-8 \mathrm{~m}$ thick massive silty-clay unit is correlative to the interval of 20 silty varves with dispersed grains of sand and gravel. This interval is tentatively correlated with the stagnation of the ice margin at the Pandivere-Neva (13.5-13.3 ka BP) ice-marginal line.

7. From the distribution, surface topography and facies build-up of the varved clay complex, the minimum water-level at 0 to $-2 \mathrm{~m}$ a.s.l. in Pärnu area is concluded and attributed to the Yoldia Sea stage after the Billingen drainage event.

\section{Acknowledgements}

Financial support for this investigation was received from the Estonian Science Foundation Grants 6992, 9107 and from the Estonian Research Council Grant SF0180048s08. Kristel Kirsis, Raul Reinson, Karin Pai and Tônn Tuvikene are acknowledged for their field and laboratory assistance. The critical comments of Dr. Vitalijs Zelchs and an anonymous reviewer are greatly appreciated.

\section{References}

Andrén, T., Björck, S., Andrén, E., Conley, D., Zillén, L. \& Anjar, J., 2011. The development of the Baltic Sea basin during the last 130 ka. In: Harff, J., Björck, S. \& Hoth, P. (eds.) The Baltic Sea basin, Springer, pp. 75-97.

Andrén, T., Lindeberg, G. \& Andrén, E., 2002. Evidence of the final drainage of the Baltic Ice Lake and the brackish phase of the Yoldia Sea in glacial varves from the Baltic Sea. Boreas 31, 226-238.

Björck, S., 1995. A review of the history of the Baltic Sea, 13.08.0 ka BP. Quaternary International 27, 19-40.

De Geer, G., 1884. Om möjliheten af att införa en kronologi för Istiden. Geologiska Föreningens i Stockholm Förhandlingar 7, 3 .

De Geer, G., 1940. Geochronologia Suecica Principles. Kungliga Svenska Vetenskapsakademiens handlingar, Ser III 18(6), $367 \mathrm{p}$.

Hang, T., 2001. Proglacial sedimentary environment, varve chronology and Late Weichselian development of the Lake Peipsi, eastern Estonia. Quaternaria A 11, 44 pp.

Hang, T., Talviste, P., Reinson, R. \& Kohv, M., 2007. Proglacial sedimentary environment in Pärnu area, western Estonia as derived from the varved clay studies. In: Johansson, P. \& Sarala, P. (eds.) Applied Quaternary research in the central part of glaciated terrain, Geological Survey of Finland, Special Paper 46, 79-86.

Hang, T., Kohv, M. \& Pai, K., 2008. Proglacial sedimentary environment in Pärnu Bay, eastern Baltic Sea. In: Lisicki, S. (ed.) Quaternary of the Gulf of Gdansk and lower Vistula regions in northern Poland: sedimentary environments, stratigraphy and palaeogeography, Polish Geological Institute, Frombork, p. 25-27.

Hang, T., Kohv, M., Pai, K. \& Tuvikene, T., 2010. Proglacial varves indicate the stagnation of ice terminus during the formation of Pandivere-Neva ice marginal formations in eastern Baltic. In: Ice, Water, Humans - Quaternary landscape evolution in the Peribaltic region. Conference proceedings of 12 th annual meeting of the INQUA Peribaltic working group, 13.-17. September 2010, Greifswald, 28-29.

Kadastik, E. \& Kalm, V., 1998. Lithostratigraphy of Late Weichselian tills on the West Estonian Islands. Bulletin of the Geological Society of Finland 70, 5-17.

Kalm, V., 2006. Pleistocene chronostratigraphy in Estonia, southeastern sector of the Scandinavian glaciation. Quaternary Science Reviews 25, 960-975.

Kalm, V., 2010. Ice-flow pattern and extent of the last Scandinavian Ice Sheet southeast of the Baltic Sea. Quaternary Science Reviews 44, 51-59.

Kalm, V., Raukas, A., Rattas, M. \& Lasberg, K., 2011. Pleistocene Glaciations in Estonia. In: Ehlers, J., Gibbard, P.L. \& Hughes, P.D. (eds.) Developments in Quaternary Science, Vol. 15, Amsterdam, The Netherlands, pp. 95-104. 
Karukäpp, R. \& Raukas, A., 1997. Deglaciation history. In: Raukas, A. \& Teedumäe, A. (eds.) Geology and mineral resources of Estonia. Estonian Academy Publishers, Tallinn, pp. 263-267.

Kask, J. \& Kask, A., 2004. Coastal processes in the inner part of the Pärnu Bay. In: Puura, I., Tuuling, I. \& Hang, T. (eds.) The Baltic: the Eighth Marine Geological Conference. Abstracts. Excursion guide, Institute of Geology, University of Tartu, Tartu, p. 25.

Kohv, M., Talviste, P., Hang, T., Kalm, V. \& Rosentau, A., 2009. Slope stability and landslides in proglacial varved clays of western Estonia. Geomorphology 106, 315-323.

Kohv, M., Talviste, P., Hang, T. \& Kalm, V., 2010. Retrogressive slope failure in glaciolacustrine clays: Sauga landslide, western Estonia. Geomorphology 124, 229-237.

Kvasov, D., 1979. The Late-Quaternary history of large lakes and inland seas of eastern Europe. Annales Academiae Scientarium Fennicae, A III 127, 1-71.

Lundqvist, J. \& Saarnisto, M., 1995. Summary of the project IGCP-253. Quaternary International 28, 9-17.

Lutt, J., 1987. Sedimentation in the Pärnu Bay. Proceedings of the Academy of Sciences of the Estonian SSR, Geology 36, 166-173 [in Russian, English summary].

Mangerud, J., Jakobsson, M., Alexanderson, H., Astakhov, V., Clarke, G. K.C., Henriksen, M., Hjort, C., Krinner, G., Lunkka, J-P., Möller, P., Murray, A., Nikolskaya, O., Saarnisto, M. \& Svendsen, J.I., 2004. Ice-dammed lakes and rerouting of the drainage of northern Eurasia during the Last Glaciation. Quaternary Science Reviews 23, 13131332.

Munsell Colour, 1998. Munsell Soil Color Charts. GretagMacneth, New Windson, New York.

Pirrus, E., 1968. Estonian varved clays. Valgus, Tallinn, 144 pp [in Russian, English summary].

Raukas, A., Kalm, V., Karukäpp, R. \& Rattas, M., 2004. Pleistocene glaciations in Estonia. In: Ehlers, J. \& Gibbard, P. (eds.) Quaternary Glaciations - Extent and Chronology, Elsevier, Amsterdam, pp. 83-91.

Raukas, A., Rähni, E. \& Miidel, A., 1971. Marginal glacial formations in North Estonia, Valgus, Tallinn, 226 pp [in Russian, English summary].

Rosentau, A., Vassiljev, J., Hang, T., Saarse, L. \& Kalm, V.,
2009. Development of the Baltic Ice Lake in eastern Baltic. Quaternary International 206, 16-23.

Rosentau, A., Veski, S., Kriiska, A., Aunap, R., Vassiljev, J., Saarse, L., Hang, T., Heinsalu, A. \& Oja, T., 2011. Palaeogeographic model for the SW Estonian coastal zone of the Baltic Sea. In: Harff, J., Björck, S. \& Hoth, P. (eds.) The Baltic Sea basin, Springer, 165-188.

Saarnisto, M. \& Saarinen, T., 2001. Deglaciation chronology of the Scandinavian ice sheet from the east of Lake Onega basin to the Salpausselkä end moraines. Global and Planetary Change 31, 387-405.

Saarse, L., 1992. Textural and structural characteristics of the Estonian varved clays. In: Saarnisto, M. \& Kahra, A. (eds.) Laminated sediments. Proceedings of the workshop at Lammi Biological Station, 4-6 June, 1990. Geological Survey of Finland, Special Paper 14, 55-63.

Saarse, L. \& Pirrus, E., 1988. Lithology and formation of the Estonian varved clays. In: Punning, J.-M., (ed.) Estonia. Geographical research. Estonian Academy Publishers, Tallinn, pp. 73-83.

Stevens, R., 1987. Glaciolacustrine fine sediments in southwestern Sweden: late-Weichselian - Holocene lithostratigraphy, depositional environments and varve formation. Publ. A 54, Dissertation, Chalmers University of Technology and University of Goteborg, 20 p.

Talviste, P., 1988. Subdivision of varved clay complex in Pärnu. In: Masso, T. \& Rattasepp,T. (eds.) Abstracts of IX Estonian Geotechnical Conference, Tallinn. ”PI Kommunaalprojekt" Publishers, Tallinn, pp. 35-36 [in Estonian].

Tavast, E. \& Raukas, A., 1982. The bedrock relief of Estonia. Valgus, Tallinn, 194 pp [in Russian, English summary].

Vassiljev, J., Saarse, L. \& Rosentau, A., 2011. Palaeoreconstruction of the Baltic Ice Lake in the Eastern Baltic. In: Harff, J., Björck, S. \& Hoth, P. (eds.) The Baltic Sea basin, Springer, pp. 189-202.

Vilo, A., 1986. Engineering geology. University of Tartu, Tartu, 109 pp [in Estonian].

Veski, S., Heinsalu, A., Klassen, V., Kriiska, A., Lôugas, L., Poska, A. \& Saluaar, U., 2005. Early Holocene coastal settlements and palaeoenvironment on the shore of the Baltic Sea at Pärnu, southwestern Estonia. Quaternary International 130, 75-85. 